\title{
Guiding principles of good tax policy: Is there an association between the principles of the income tax of Nepal and the principles of good tax policy suggested by AICPA?
}

\author{
Jit Bahadur K.C. \\ Associate Professor, Nepal Commerce Campus, Faculty of Management, T.U.
}

\begin{abstract}
Purpose - This article aims to examine the association between principles of income tax in Nepal and the principles of good tax policy prescribed by AICPA.

Materials and methods - This study uses both primary and secondary data. For the primary data, the study obtained data from several individuals using the Likert type scale questionnaires. To obtain the answer upon research questions and to reach into the conclusion, the study used the Chi-square and summated rating scale.
\end{abstract}

Findings - The study found an association between the principles of income tax in Nepal and the guiding principles of the good tax policy suggested by AICPA. Only on three principles (i.e., certainty, information security and economic growth and efficiency) out of the twelve guiding principles came into the acceptance of $H_{0}$ (null hypothesis) while others came into the acceptance of $H_{1}$ (alternative hypothesis). However, the study concludes that Nepal needs reform/s to its income tax principles to make them compatible with the principles of other countries.

Practical implications - Theory and practice both are complementary to each other. Every theory is worthless in the absence of practice and vice versa. The theory, which people perceive as simple, progressive, and democratic is fundamental and practical. Thus, this writing keeps crucial importance in the government revenue sector and suggests to be practical after reforming the required policy.

Originality/value - This is survey research to find out the association between the principles of income taxation in Nepal and the guiding principles of good tax policy suggested by the AICPA. For which, the author prepared this product using both primary and secondary sources of data based on Kathmandu valley. Thus, this is original writing in this subject.

Keywords: Equity, certainty, effectiveness, neutrality, economic growth, etc.

\section{Background}

Tax is a vital source of government revenue. This compulsory levy plays a role in government finance as a heart plays in the human body. It is an inseparable element of levy to complete the duties and 
Silver Jubilee Issue - 2019

functions of the government, which are vitally important to show the existence of the government in a state. Therefore, the intellectual of public finance argue that taxation is an essential levy of a government because they cannot alive their existence without tax revenue. Thus, governments have legally composed such levy of taxation in the form of income tax act as compulsory payment without direct quid pro quo between payers and public authority.

Pubic finance specialists argue that the main objective of any tax system is to raise revenue for the government but they also advocate that tax should be fair, ethical, societal, bearable, neutral, justifiable, etc. If not so, the government neither can provide justice to its citizens nor can raise the desired amount of tax to its treasury.

History reveals that at the beginning the levy of tax was not only compulsory it was a coerced levy too. However, in this democratic era, a coerced levy is not possible. In tax, the taxpayers are obligued about the compulsory without direct quid pro quo payment. Thus, with the democratic system various tax experts, scholars, researchers, etc., have argued certain guidelines considering the rights and duties of both (i.e., taxpayers and public authorities) to systematize the tax system worldwide. Theorists, scholars, experts believe that the guiding principles of tax policy are basic concepts and norms to judge the tax system in a nation.

The tax regime of a country is a key policy instrument that significantly influences the investment. Thus, the thought of the guiding principles of good tax policy was required since the very beginning but that was not commonly completed globally. Considering this fact of lack, the Association of International Certified Professional Accountants (AICPA (2017 [2001]) suggested the 12 unique tenets of the good tax policy for all the governments of the universe. However, they are not mandatory. Many developed and developing countries have adopted those guiding principles. However, we are unsure about the adoption of those principles in Nepal.

Thus, in this article, we tried to assess the Nepalese tax system, to determine whether this system is associated with those guiding principles of good tax policy suggested by the AICPA, which the experts consider adequate to set the tax system in any country.

\section{Problems}

More than six decades ago, Nepal introduced a system of the periodic plan in 1956 and recently it already completed 14 periodic plans. However, Nepal remained one of the least developed countries in the world and it is a comparatively low-income country in the South Asian region.

Among the developing countries, the tax to GDP ratio of Nepal is nearly lowest. The government of Nepal receives $75 \%$ of the tax revenue from indirect taxes while developed countries collect a huge portion of their tax revenue from direct taxes (K.C., 2017). The theory of direct tax regards the progressive, which effects minimally to the lower class people.

Income tax is the most important but among taxes, it is complex, vague and critical. Most experts consensus with the view that a series of sections, subsections, paragraphs, subparagraphs, clauses, subclauses and interrelated provisions between those series create confusion to the taxpayers as well as government authorities. Thus, it requires a wide range of expert knowledge in the calculation to complete the several steps and to obtain an exact figure of income tax liability. For example, Adhikari (2002) opined that income tax Acts of Nepal were and are vague, ambiguous and confusing. In the same way, Pyakurel, Kushiyait and Adhikari (2013) suggested that an essential reform in the tax laws and tax administration of Nepal to broaden the tax base.

The principles, policies and goals of the revenue collection of the government concern in many cases but the tax officials use their conscience and deny the provision of tax law. The practice of the income tax is under a very old concept (i.e., 18th century). For example, Hamilton (1791) argued, "Taxation has long been practiced as an art, but has never been fully explained" (p. 1). However, in the case of taxation, there has been no exception to the claim of Hamilton to date. Similarly, IMF, OECD, UN and the World 
Bank (2011) observed that the challenge of weak tax administration, taxpayers in low morale and noncompliance in the developing countries.

Thus, in this article, we tried to assess the prevailing principles of income taxation to assist the government theories, principles and guidelines in Nepal based on the suggested guiding principles of good tax policy of the AICPA.

\section{Research questions}

Based on the review of the literature on the principles of taxation, we developed the underlying question for the given $1 \mathrm{dfcv} 2$ attributes prescribed by the AICPA for assessing the tax principles, which the Government of Nepal has adopted:

Is there an association between the principles of income tax in Nepal and the guiding principles of good tax policy suggested by the AICPA?; (i.e., (1) equity and fairness, (2) certainty, (3) convenience, (4) effectiveness, (5) information security, (6) simplicity, (7) neutrality, (8) economic growth and efficiency, (9) transparency, (10) minimum tax gap, (11) accountability to taxpayers and (12) appropriate government revenues).

\section{Objectives}

The objective of this study is to examine the association between the principles of income tax in Nepal and the guiding principles of good tax policies suggested by AICPA; (i.e., (1) equity and fairness, (2) certainty, (3) convenience, (4) effectiveness, (5) information security, (6) simplicity, (7) neutrality, (8) economic growth and efficiency, (9) transparency, (10) minimum tax gap, (11) accountability to taxpayers and (12) appropriate government revenues).

\section{Research hypothesis}

For the examination of the association between the income tax principles and the guiding principles of good tax policy suggested by the AICPA, we formulated the following hypotheses:

$H_{0} \quad$ There is no association between the principles of income taxation in Nepal and the guiding principles of good tax policy suggested by the AICPA; (e.g. (1) equity and fairness, (2) certainty, (3) convenience, (4) effectiveness, (5) information security, (6) simplicity, (7) neutrality, (8) economic growth and efficiency, (9) transparency, (10) minimum tax gap, (11) accountability to taxpayers and (12) appropriate government revenues).

$H_{I} \quad$ There is an association between the principles of income taxation in Nepal and the guiding principles of good tax policy suggested by the AICPA; (e.g. (1) equity and fairness, (2) certainty, (3) convenience, (4) effectiveness, (5) information security, (6) simplicity, (7) neutrality, (8) economic growth and efficiency, (9) transparency, (10) minimum tax gap, (11) accountability to taxpayers and (12) appropriate government revenues).

\section{Scope and limitations}

This article highlights the association between the principles of income tax in Nepal and the guiding principles of good tax policy suggested by the AICPA. Particularly, this helps those persons (i.e., professors, consultants, chartered accountants, auditors, managers, etc.) who are willing to gain knowledge about the principles of income tax in Nepal and their association with other principles. "Tax system is a set of taxes, fees, duties, and other payments, charged in accordance with established procedures" (Nazarov, 2016, p. 2195). However, this article solely concerns with the principles of the income tax system, not to the tax system. 


\section{Literature survey}

This section describes a vivid picture of the overall ideas about the subject of principles of income taxation. Therefore, it includes several pieces of works of literature about this conception published in the earlier days.

\section{Concept of tax/taxation}

Taking into account the importance of taxation, several studies attempted on the concept of taxation to delineate a good tax system. The concept and definition of tax and taxation came into modernized gradually in later years. Ricardo (1817) defined, "Taxes are a portion of the produce of the land and labour of a country, placed at the disposal of the government; and are always ultimately paid, either from the capital or from the revenue of the country" (p. 101). The economist, McCulloch (1863) also composed the definition, "A tax is a portion or the value of a portion, of the property or labour of individuals taken from them and disposed of by government" (p. 1). After that Taussig viewed, "The essence of a tax, as distinguished from other charges by Government is the absence of a direct quid pro quo between the taxpayer and the public authority" (Dalton, 1948, p. 26). Similarly, Owens (1985) supported the view of the Organization for Economic Cooperation and Development (OECD), "Compulsory, unrequited payments to general government" (p. 95). However, McGee (1997) claimed that a tax is a coercive levy upon the citizens. Similarly, the Collins Dictionary (2017) describes, "A compulsory financial contribution imposed by a government to raise revenue, levied on the income or property of persons or organizations, on the production costs or sales prices of goods and services, etc."

The above-quoted definitions state that governments impose and raise taxes. Therefore, it is a government's responsibility to collect the tax revenue to meet the state expenditures for public welfare.

However, there are other revenues of the government, which are also compulsory. For example, fine, which the Court imposes, is also compulsory, but it differs from a motive of the collection. The other sources of government like price and fee (For example; in the case of fees, Lyon (1914) clarified that fees meet the cost of any public service) do not contain the characteristics of quid pro quo. Therefore, the collection of non-tax revenue of the government significantly differs from the tax revenue. The major difference is the motive of the collection. The motive of imposing and collecting taxes is raising the revenue but other nontax items do not concern about the raising of revenue.

Therefore, in succinctly, taxes include the concept of quid-pro-quo between the taxpayers and government authorities while non-taxes concern the conception of pure exchange between those parties.

\section{Objectives and methods of taxation}

A responsible government has to think twice before imposing the tax upon its citizens. The government is to complete the norms and values of taxation because the imposition of a tax alters the economic decisions of its citizens. Therefore, governments consider some sort of norms and values while levying the tax. In this circumstance, experts on public finance suggest the five objectives, four principles and three methods of taxation. 


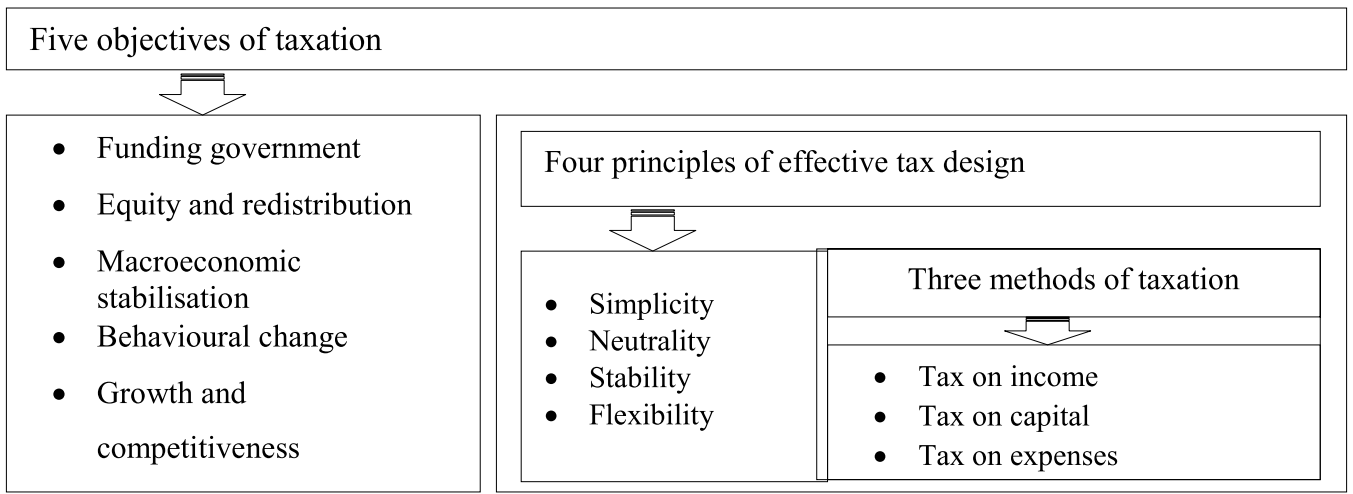

Fig. 1. A framework of the objectives, principles, and method of the taxation

Source: Authors elaboration based on the report of the Scottish Government (2013)

The main objective of the taxation is to fund the government and then towards completion of the redistribution for equity, macroeconomic stabilization, to change the buying behaviour of the consumer and economic growth. Then, the tax should be simple, neutral, stable, and flexible in principles. Similarly, the tax should levy on either income or capital or expense. In addition, its main objective is to fund the government and then towards completion of the redistribution for equity, macroeconomic stabilization, to change the buying behaviour of the consumer and economic growth of the country. Therefore, the tax should be simple, neutral, stable, and flexible in principles.

\section{Contemporary reasons and goals of taxation}

Taxes are the foremost important and inseparable sources with government functioning. Without a source, the government neither can show his existence nor sustain it. Researchers of the taxation claim that there are several goals of taxation. For example, Avi-Yonah (2006) argued for the three goals (i.e., revenue, redistribution and regulation of economy) of taxation. However, Kabinga (2016) explained the five goals of taxation. In short, they are called "5 Rs" in the field of taxation.

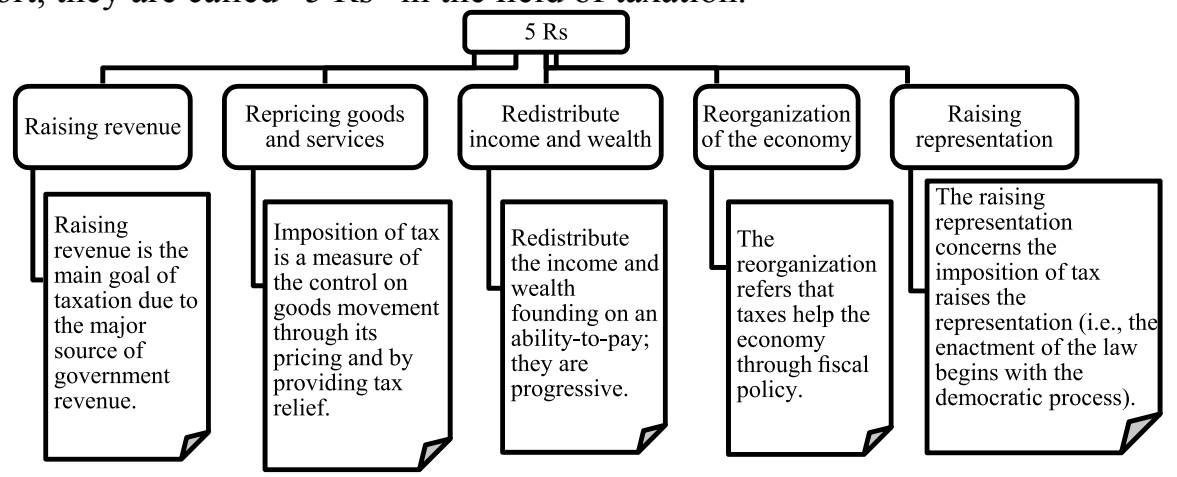

Fig. 2. Goals of taxation

Source: Author's elaboration based on the view of Kabinga (2016).

\section{Functions of taxation}

The experts of the public finance consider the following five functions of taxation: (a) fiscal and economic, (b) redistribution, (c) regulating: (i) stimulating, (ii) de-stimulating and (iii) regeneration, (d) controlling and (e) promoting.

\section{Classification of taxes}

There is a number of taxes under several classifications; however, they can be classified into six categories based on nature, form, aim, essence and methods of taxation. In the modern tax system, the 
Silver Jubilee Issue - 2019

following classifications are commonly used.

Bases of classification

The bearing of the burden

Taxing object

Methods of determination tax

Method determination of rates

Aims/purposes

Scope

\section{Classification}

Direct and indirect

Personal, property and excise

Specific and ad-valorem duties

Progressive, proportional, regressive and degressive

Single and multiple taxes

National tax and local tax

Fig. 3 Classification of taxes

Source: Author's compilation

The classifications of taxes are complementary as well as supplementary to each other, but they are not contradictory and cannot compete with each other. Among the various bases for classification of taxes, the classification based on bearing of the burden is a major one in the taxation literature.

\section{Principles of taxation}

Principles of taxation are those formal guidelines, which are widely accepted and discussed. Most experts carefully view accepted guidelines while proposing, discussing and implementing income tax laws.

The father of economics, Smith (1776) composed four maxims of taxation, which are still influential for guidelines on the scope of taxation. Nowadays, those four principles come into the taxation literature under the catchwords of equality, certainty, convenience and economy. However, after the 50 years, a leading British economist, Ricardo (1817) criticized Smith's opinion on taxation. He put emphasis on the important insight that any society undergoes stages in which the "whole produces of the earth" are allotted differently to the three classes of the community, namely the owner of the land, the owner of the stock and capital and labourer via rent, profit and wage and as a result, 'laws' are needed, 'which regulate this distribution' via taxation. However, the thoughts of Smith are still important today as they were in the past.

There are various criteria to judge a good tax system. Among them, fairness, adequacy, simplicity, efficiency, and stability are the basic attributes to judge a tax system. Several studies have argued for the good tax system. For example; Weston (1903), Vedder and Gallaway (1998), Wise and Berger (2010), Centre for Accounting, Governance and Taxation Research, Victoria University of Wellington (2010), Listokin (2012) and Ornäs Leijon (2015) studied and emphasised that the income tax policy should have the principles of equity, efficiency and stability.

Fiore (2012) discussed the eight guiding principles of good tax policy developed by the AICPA as a framework: equity and fairness, certainty, the convenience of payment, economy, simplicity, neutrality, economic growth and efficiency, transparency and visibility, minimum tax gap and appropriate for government revenue.

AICPA (2017 [2001]) suggested that several guiding principles of good tax policy in the recent edition. Therefore, normally, the experts, scholars and researchers believe the following guiding principles of the AICPA for the good tax system while evaluating the taxation in any country. 
Table 1

Guiding principles of good tax policy of the AICPA (2017 [2001])

\begin{tabular}{|c|c|}
\hline Principles & Suggested ideas \\
\hline Equity and fairness & In similarly situated taxpayers should pay the same amount of tax. \\
\hline Certainty & The tax rules should specify the amount, place and date of tax to be paid. \\
\hline Convenience & The tax rules should consider the time of paying tax for convenience. \\
\hline Effectiveness & $\begin{array}{l}\text { The cost of collection of government and payment of the tax to the taxpayer } \\
\text { should be minimum. }\end{array}$ \\
\hline Information security & $\begin{array}{l}\text { The tax authorities should protect all the information of the taxpayers related to } \\
\text { the tax matters. }\end{array}$ \\
\hline Simplicity & $\begin{array}{l}\text { The tax law should be simple to understand and comply in a cost-efficient manner. } \\
\text { The effect of taxation should be minimum to minimise the decision of the }\end{array}$ \\
\hline Neutrality & alteration of the taxpayers. \\
\hline $\begin{array}{l}\text { Economic growth } \\
\text { and efficiency }\end{array}$ & $\begin{array}{l}\text { The tax principles should facilitate economic growth and should be productive for } \\
\text { further enhancement. }\end{array}$ \\
\hline Transparency & $\begin{array}{l}\text { The tax principles should provide information on how and when that tax exists } \\
\text { upon them and others. }\end{array}$ \\
\hline Minimum tax gap & The tax principles should minimise compliance. \\
\hline $\begin{array}{l}\text { Accountability to } \\
\text { taxpayers }\end{array}$ & $\begin{array}{l}\text { The information on development, modification and purpose of the tax law should } \\
\text { be clear to the taxpayers. }\end{array}$ \\
\hline $\begin{array}{l}\text { Appropriate } \\
\text { government } \\
\text { revenues }\end{array}$ & $\begin{array}{l}\text { The tax system should yield adequate revenue to the government with appropriate } \\
\text { predictability, stability and reliability. }\end{array}$ \\
\hline
\end{tabular}

Source: As suggested by AICPA (2017 [2001])

The study proves that most of the tax authorities of both developed and developing countries seriously consider those 12 principles suggested by AICPA (2017 [2001]) while they draft the tax policy for their revenue collection strategy.

\section{Tax principles and policies in Nepal}

In this modern era, the countries are going to modernizing their revenue administration systems to make payment of taxes simpler and convenient. In Nepal, the Inland Revenue Department (IRD) recently (in 2002) introduced the new income tax law by compiling all the income tax relating provisions into one.

Evidence shows that taxation existed even about a thousand years ago in the past. In ancient civilizations, the Greeks, Romans and Egyptians levied different types of taxes on their citizens to finance the military operations, public goods and services including the border securities. Europe started tax on property, land rent, salary and gains or profit on the profession in medieval times. In 1783, William Pitt became the Prime Minister of Britain and imposed the first general income tax during the Napoleonic wars in 1799 .

The imposition of taxes was started in the Kirat dynasty in ancient Nepal. However, there was not a rule of law for systematic taxation. In modern Nepal, Rana ruled its Oligarchy system in Nepal since 1846 AD for 104 years. In 1950, the Rana regime ended and the democratic system was introduced. However, the modern income tax system began in 1960 from the contemporary elected government. Therefore, the income tax system is a recent phenomenon in Nepal. Until to date, the citizens of Nepal have experienced the four income tax acts. They are: (a) Business, Profit and Salary Tax Act 1960 (BPSTA 1960), (b) Income Tax Act (ITA) 1962, (c) ITA 1974 and (d) ITA 2002. Thus, we substantially discuss the tax principles and 
policies of Nepal accordingly.

\section{The BPSTA, 1960 (2017)}

Nepal formally imposed an income tax in 1960, enacting the BPSTA, 1960, which was the first Act and adopted the following policies (Agrawal, 1978):

- $\quad$ tax on business profit and salary income and allowed their real expenses

- the place of payment

- tax deduction at the source

- the calculations of tax liabilities:

(a) in just subsequent year for the business profit and

(b) for the salary income in the income year

- the unlimited power of best judgment to a tax officer if the failure to file the return of income and if falsely filed

- the provision of fine for the fraud filed

- the first appellate court in the case of the tax dispute

- a partial rebate to industries and small scale industries

- the government of Nepal replaced it by the ITA 1962 claiming narrow to it.

\section{The ITA 1962 (2019)}

The ITA, 1962 was an extended version of the BPSTA, 1960. It specified;

- $\quad$ divided all the incomes into nine heads

- residential status of the taxpayers

- $\quad$ assessment, collection and deduction procedures

- $\quad$ basis of best judgment

- $\quad$ power to constitute net income assessment committee

- $\quad$ system of instalment and advance payment of tax

- reassessment and rectification of arithmetic errors

- rebate of income tax for a period not exceeding ten years.

- carry forward of losses for the two subsequent years

- the agriculture income into the tax net for the first time

- $\quad$ income exempt from payment of tax on agriculture income

- $\quad$ Finance Act 2030 (1973) again restored agriculture income under the purview of the income tax (Agrawal, 1978).

- the His Majesty Government of Nepal (HMG/N) replaced this act by enacting ITA 1974.

\section{The ITA 1974 (2031)}

The ITA 1974 is the third income tax law, which specified the following:

- clarified some definitions relating to tax, assessment and year of income, income, personal status of the taxpayer and non-resident taxpayers.

- $\quad$ Divided all the income into the five heads

- $\quad$ specified methods of computing net income from each source

- $\quad$ specified the deductible and non-deductible expenses

- made obligatory for taxpayers to register their industries, business, profession or vocation

- made obligatory of notification if any change in place and business activities

- $\quad$ applied self-assessment for the first time in Nepal

- $\quad$ provision of carry-forward of loss for the three years

- provided life insurance premium as a deduction

- required to keep books of account of all the sources of the incomes and to preserve them for 
the next six years

- $\quad$ applied reassessment and additional assessment

- $\quad$ procedures for assessment, collection, payment and refund of income tax

- $\quad$ procedures of search, seize and penalize in the case of tax evasion

- remained in the effective until 2002 and the ITA, 2002 replaced it.

\section{The ITA, 2002 (2058)}

When ITA, 1974 enforced as a prevailing law, the most experts of public finance claimed that a number of deficiencies such as a narrow tax base, the wilful power of the tax officer, vague, raw, ineffective, etc. Thus, the government enacted ITA 2002 to remove all the deficiencies of the previous acts, which include the following features:

- an act of compilation of all the provisions relating to income tax.

- based on the fully self-assessment system.

- divided all the sources of income into the three sources based on the factors of production such as land, labour and capital

- $\quad$ allowed the real expenses for the deduction

- defined the basic tax-related term in detail.

- $\quad$ simplifies the method of depreciation in block base depreciation.

- $\quad$ specifies the method of tax accounting.

- clarifies the exemption limit of the personal income tax

- $\quad$ specifies the loss offset and carryover provisions

Taxation is not a new thing in many societies in the world. However, the system of taxation differs in every country significantly by its own factors of the endowment. Consequently, countries use different types of taxes.

The review of the principles of income taxation in Nepal found that a mature with the change of time to some extent.

\section{Methodology, materials and methods}

This study adopts both sources of data: primary and secondary. They include acts, rules, law-books, legal journals, books, dictionaries, internet resources, case reports, and reports encyclopaedias, etc.

The study employed a survey design because the survey is the most common technique for gathering data in the research (Bhattacherjee, 2012). For this purpose, we used a five-point Likert type scaled questionnaires - ordinal data starting from strongly agree, agree, unsure, disagree, strongly disagree - to collect data from 130 persons randomly selected from university teachers, chartered accountants, registered auditors and managers of the firms in Kathmandu using drop-off survey methods. However, only 125 respondents (96.15\%) responded to the questionnaires by returning their views in the form of Likert type scale questionnaires.

To test the hypothesis, the study used Chi-square with a 5\% level of significance. The decision rule is to reject the null hypothesis if the calculated value is greater than the critical value and accepted if it occurs otherwise. We calculated the value of Chi-square using the following formula:

$$
\begin{aligned}
& \chi^{2}=\Sigma \frac{(O-E)^{2}}{E} \\
& \text { Where, } \\
& O=\text { Observed frequency, } \\
& E=\text { Expected frequency } \\
& \text { Level of significance }=0.05 \\
& \text { Degree of freedom }=n-1
\end{aligned}
$$


Therefore, the degree of freedom is to $d f=5-1=4$. Thus, the table value of the $\chi^{2}$ from that 5 degree of freedom at the $5 \%$ significance level, the table value is 9.49 . Theoretically, the Chi-square test requires two independent variables (observed and expected value) to test the significance. The outcome of the zero value of the Chi-square represents the full association while the difference in the greater value represents greater variance between those variables.

Rensis Likert invented the summated rating scale in 1932 (Spector, 1992). Shukla and Sharma (2017) argued that the attitude is "the degree of positive or negative affect associated with some psychological object. The scale is a continuum from highest to lowest points and has intermediate points in between these two extremities" (p.230). To find out the summated rating scale, we follow the following process.

The developed scale includes 12 items. Each item in the attitude scale has to be responded on fivepoint of the continuum (i.e., 'strongly agree', 'agree', 'unsure', 'disagree' and 'strongly disagree'). For those Likert type scales the weight assigned 5, 4, 3, 2 and 1 respectively.

The total score of a respondent for 12 items on the scale is his individual attitude score. Thus, in this way, the maximum obtainable score as per the present attitude scale is 60 , whereas the minimum obtainable score is 12 .

\section{Result and interpretation}

This section presents the results of the collected data in a systematic way to find out the major two aspects: (a) to synthesize the principles of taxation in Nepal and (b) to examine the association between underlying principles of income tax of Nepal and the guiding principles of good tax policy suggested by the AICPA empirically.

According to the research questions and hypotheses, we have twelve crucial questions and hypotheses. Thus, we present the results and test the hypotheses accordingly.

Table 2

Result of Chi-square and summated rating scale

\begin{tabular}{|c|c|c|c|c|c|c|c|}
\hline \multirow{3}{*}{ Questions } & \multicolumn{5}{|c|}{ Chi-Square } & \multicolumn{2}{|c|}{$\begin{array}{c}\text { Summated Rating } \\
\text { Scale }\end{array}$} \\
\hline & \multicolumn{3}{|c|}{ Response \% } & \multirow{2}{*}{$\chi^{2}$} & \multirow{2}{*}{ Hypothesis } & \multirow{2}{*}{ Mean } & \multirow{2}{*}{ Rating } \\
\hline & Agree & Unsure & Disagree & & & & \\
\hline Equity and fairness & 36.80 & 8.80 & 54.40 & 21.95 & $H_{0}$ rejected & 2.816 & 10 \\
\hline Certainty & 40.80 & 14.40 & 44.80 & 7.05 & $H_{0}$ accepted & 2.936 & 9 \\
\hline Convenience in payment of tax & 46.40 & 9.60 & 44.00 & 10.53 & $H_{0}$ rejected & 3.032 & 6 \\
\hline Effective tax administration & 44.80 & 8.00 & 47.20 & 12.58 & $H_{0}$ rejected & 2.992 & 7 \\
\hline Information security & 42.40 & 12.00 & 45.60 & 8.43 & $H_{0}$ accepted & 2.944 & 8 \\
\hline Simplicity & 51.20 & 10.40 & 38.40 & 12.88 & $H_{0}$ rejected & 3.192 & 4 \\
\hline Neutrality & 48.80 & 6.40 & 44.80 & 14.63 & $H_{0}$ rejected & 3.040 & 5 \\
\hline Economic growth and efficiency & 35.20 & 16.00 & 48.80 & 8.74 & $H_{0}$ accepted & 2.768 & 11 \\
\hline Transparency and visibility & 57.60 & 12.80 & 29.60 & 17.39 & $H_{0}$ rejected & 3.480 & 1 \\
\hline Minimum tax gap & 50.40 & 12.80 & 36.80 & 10.22 & $H_{0}$ rejected & 3.200 & 3 \\
\hline Accountability to taxpayers & 55.20 & 10.40 & 34.40 & 15.80 & $H_{0}$ rejected & 3.336 & 2 \\
\hline \multirow[t]{2}{*}{ Appropriate government revenue } & 56.80 & 14.40 & 28.80 & 19.23 & $H_{0}$ rejected & 3.480 & 1 \\
\hline & & & & & & 3.101 & \\
\hline
\end{tabular}

Source: Authors calculation using Excel ver.13

Note:

1. Agree refers to the sum of the agree and strongly agree

2. Unsure refers to the neutral view

3. Disagree refers to the sum of the disagree and strongly disagree 
The study of the Chi-square test revealed that the acceptance of the null hypothesis only on three variables (i.e., certainty, information security and economic growth and efficiency) among the 12 variables. It means there is no association between the principles of income tax in Nepal and the guiding principles of good tax policy suggested by the AICPA on those three variables. However, there is an association between other variables (principles of income tax in Nepal) and the guiding principles of good tax policy suggested by AICPA. In other words, the study revealed that the variable other than those three reject the null hypothesis and accept the alternative hypothesis in relation to the association.

In the analysis of the summated rating scale, its total mean valued resulted that 3.101 , which means that it is towards agreeing with a negligible amount between the principles of income tax of Nepal and the guiding principles of good tax policy suggested by the AICPA. According to the rating the value 3.0 represents the neutral view while the value 4.0 represents the agree (association). Thus, the total value of summated is towards the value 4.0 with a negligible amount.

Similarly, the variables (i.e., transparency and visibility and appropriate government revenues) showed the agree (association) between the principles of income tax in Nepal and guiding principles of good tax policy suggested by the AICPA with the greater amount with the value 3.480 among the variables, which are close to the value 4.0 while economic growth and efficiency and equity and fairness showed the disagree among the 12 variables in the study.

The study of the association between the principles of income tax in Nepal and the guiding principles of good tax policy suggested by the AICPA can be concluded that it is essential to reform the tax principles of Nepal to make a good tax system in the worldview.

\section{Discussion}

History reveals that the principles of taxation are widely discussed elements of the tax system while proposing, discussing and implementing taxation laws. They (principles of taxation) were and are under discussion as human civilisation. Thus, in this section, we discuss it widely about its efforts to make a good tax system since the very beginning to date in the tax regime in order to make a change in the worldview.

The principles of taxation were applied as early as 4000 BC in Sumer (i.e., ancient country of southern Mesopotamia, in present-day Iraq) (Preez, 2018). Around 500 BC, the Chinese philosopher, Confucius formulated a $10 \%$ tax of the taxpayer's income, which was remained in an application for more than two thousand years (Adams, 2001). A scholar of Maurya Emperor of the Indian continent, Kautilya compiled and proposed 12 types of taxes and rates in $150 \mathrm{AD}$ (Rangarajan, 1992). Taxation is a specialized discipline in academia. Thus, it has an importance on the evaluation of the fundamental principles.

Table 3

Efforts of the guiding principles for good tax policy since the 18th to 21st century

\begin{tabular}{ll}
\hline \multicolumn{1}{c}{ Authors } & \multicolumn{1}{c}{ Suggested criteria and tenets } \\
\hline Smith (1776) & $\begin{array}{l}\text { systematised four maxims of taxation (i.e., equality, certainty, convenience and } \\
\text { economy) as a guideline for the principles of taxation. } \\
\text { proposed the five criteria (i.e., equity, neutrality, transparency and accountability, } \\
\text { The Carter }\end{array}$ \\
Report of & $\begin{array}{l}\text { certainty, simplicity and flexibility) of the tax system to achieve economic and social } \\
\text { objectives. } \\
\text { Canada (1966) } \\
\text { Asprey and }\end{array}$ \\
parsoposed five criteria (i.e., fairness, simplicity, efficiency and other objectives (growth \\
and stabilisation)) for the tax system (pp. 12-17) of Australia.
\end{tabular}


suggested six characteristics of a good tax structure (i.e., incentives and economic

Meade Report efficiency, distributional effects, international aspects, simplicity and costs of

(Meade, 1978) administration and compliance, flexibility and stability and transitional problems) for the United Kingdom.

Ridge and suggested the criteria for local taxes (i.e., administrative feasibility, economic

Smith (1991) efficiency, equity and accountability) for the United Kingdom. recommended the characteristics of an efficient tax system (i.e., equity or fairness,

Jackson (1994) certainty, convenience, the economy in collection and compliance and transparency) for local government.

the conference of Ottawa offered the taxation framework conditions (i.e., neutrality,

OECD (1998) efficiency, certainty and simplicity, effectiveness and fairness and flexibility) for the purpose of electronic commerce in Europe

The Institute of Chartered Accountants in England \& Wales (ICAEW, 1999) of

ICAEW (1999)

England prolonged the ten tenets (i.e., statutory, certainty, simplicity, easy to collect

and calculate, properly targeted, constant, consultation, regular review, fair and

reasonable and competitiveness) for a better tax system.

James and

Nobes (1999)

discussed the principles of taxation (i.e., efficiency, incentives, equity and

macroeconomic considerations) for the good revenue of taxation and economic

development in the society.

Founded in 1887, the AICPA, the world's largest member association representing

AICPA $(2017$

more than 418,000 AICPA members in 143 countries around the world (AICPA, 2016).

[2001])

It regards the rule-making and standard-setting for the public interest. It suggested those 12 guiding principles of good tax policy, which is a result of all the above-stated efforts.

Source: Authors synthesis elaboration based on the above sources

The principles of good tax policies are under discussion continuously. There are also a number of discussions about the other parts of the principles of taxation.

The scholars, researchers, experts or educators view the taxation from various angles and perspectives. For example, Weston (1903) viewed, "An excessive tax curtails production" (p. 59). Edgeworth (1910) proposed an equal proportional sacrifice, which first argued by Robert Edward Anderson Seligman. Wise and Berger (2010) questioned the equity of horizontal and vertical. Nhekairo (2014) opined against the tax distortion. OECD (2014) put the question of compliance costs of taxation.

Similarly, researchers, for example, MACPA's Legislative Resource Center (2007), Sawyer (2019), Hoffman, Young, Raabe, Maloney and Nellen (2019), Rolfe (2020), supported the principles and they have been suggesting to apply those principles. reforming.

Thus, from the discussion, the study suggests that Nepal cannot be an exception for the case of tax

\section{Conclusion}

Revenue raised through taxation is more sustainable than reliance on borrowing. However, to raise adequate revenue, it needs to have an effective, appropriate, justifiable and environmentally adopted tax system, which should be developed by taking into account the principles discussed.

Considering those facts, several economists, scholars and experts of public finance, management, and legal sectors discussed in many qualities and principles. In recent years, the AICPA, a worldwide consulted 
and attributed principles of good tax policy suggested as a framework for evaluating the tax system.

The study found acceptance of $H_{0}$ (null hypothesis) only three principles (i.e., certainty, information security and economic growth and efficiency) which mean there is not a significant association between the tax principles of Nepal and the guiding principles of good tax policy suggested by the AICPA. In this study, the other nine principles found that acceptance of $H_{l}$ (alternative hypothesis) which means association between the principles of income tax of Nepal and the guiding principles of good tax policy suggested by the AICPA.

Although, the study concludes that Nepal needs to reform its income tax principles to make them compatible with the principles of other countries to optimising economic growth, ensuring equity and facilitating simplification in the case of tax revenue for our country.

\section{Scope for further study}

This study belongs to the area of Kathmandu. By the various constraints, we collected the data from limited areas and respondents, which may or may not represent the whole population and may or may not generalize in the context of such type of research. Thus, we suggest further study for this research using a wide range of areas and respondents to make it more reliable and generalizable.

\section{References}

Adams, C. (2001). For good and evil: The impact of taxes on the course of civilization. Lanham, MD: Madison Books.

Adhikari, B. D. (2002). Income tax law: Then and now. Kathmandu: Bhrikuti Academic Publication.

Agrawal, G. R. (1978). Resource mobilization for development. Kirtipur: Centre for Economic Development and Administration.

AICPA. (2016). Annual Report 2016. North Carolina: The American Institute of Chartered and Public Accountants.

Asprey, K. W., \& Parsons, R. W. (1975). Report - Taxation Review Committee. Australia: Commonwealth Taxation Review Committee, Australia.

Association of International Certified Professional Accountants. (2017 [2001]). Guiding principles of good tax policy; A framework for evaluating tax proposals. New York: Association of International Certified Professional Accountants.

Avi-Yonah, R. S. (2006). The three goals of taxation. Tax Law Review, LX(1), 1-28. Retrieved from https:// repository.law.umich.edu/articles/40

Bhattacherjee, A. (2012). Social science research: Principles, methods, and practices. South Florida: Textbooks Collection. Book 3. Retrieved from http://scholarcommons.usf.edu/oa_textbooks/3

Carter Report - 2, Canada. (1966). The use of the tax system to achieve economic and social objectives. Canda: Report of the Royal commission on Taxation.

Centre for Accounting, Governance and Taxation Research, Victoria University of Wellington. (2010). A tax system for New Zealand's future: Report of the Victoria University of Wellington tax working group. Wellington: Victoria University of Wellington.

Collins English Dictionary. (2017, December 17). Definition of tax. Retrieved from Collins English Dictionary: https://www.collinsdictionary.com/dictionary/english/tax

Dalton, H. (1948). Principles of public finance. London: Routledge \& Kegan Paul Limited.

Edgeworth, F. Y. (1910). The subjective element in the first principle of taxation. The Quarterly Journal of Economics, XXIV(3), 459-470.

Fiore, N. (2012). Guiding principles of good tax policy. (N. Fiore, Ed.) Journal of Accountancy. Retrieved from https://www.journalofaccountancy.com/issues/2002/feb/guidingprinciples ofgoodtaxpolicy.html

Hamilton, A. (1791). An enquiry into the principles of taxation, chiefly applicable to articles of immediate consumption. Dame-Street: William Jones. 
His Majesty Government of Nepal (2019). Income tax act, 1962. Kathmandu:Ministry of Law, Justice and Parliament Affairs.

His Majesty Government of Nepal (2031). Income tax act, 1974. Kathmandu:Ministry of Law, Justice and Parliament Affairs.

Hoffman, W. H., Young, J. C., Raabe, W. A., Maloney, D. M., \& Nellen, A. (2019, January 17). Individual income taxes. Retrieved from Google Books: https://books.google.com.np/ books? id=RMK1DgAAQBAJ\&pg=SA1-PA8\&lpg=SA1-PA $8 \& d q=$ guiding + principles + of + good + tax + policy $+\mathrm{a}+$ framework + for + evaluating + tax + proposals \& source $=$ bl\&ots $=$ mW5i4ThlC $4 \&$ sig $=$ ACfU3U1LhAOlNYby7UKGjAOUOk2zIKw6ng\&hl=en\&sa=X\&ved=2ahUKEwilstePhvvnAhXm

ICAEW. (1999). Towards a better tax system. England: The Institute of Chartered Accountants in England \& Wales. Retrieved from https://www.icaew.com/technical/tax/towards-a-better-tax-system/tentenets-of-tax

IMF, OECD, UN and World Bank. (2011). Supporting the development of more effective tax systems: G-20 Seoul Summit: A report to the G-20 development working group. G-20 Seoul Summit (pp. 1-54). Seoul: IMF, OECD, UN and World Bank.

Jackson, P. M. (1994). Efficient local government finance: The never ending story. In F. Terry, Towards restructuring: The dimensions of change in local government (pp. 55-62).

James, S., \& Nobes, C. (1999). The economics of taxation: Principles, policy, and practice. Birmingham: Fiscal Publications.

K.C., J. B. (2017). Tax-to-GDP ratio in Nepal: A critical analysis. The Nepalese Management Review, $X V I I I(1), 78-92$.

Kabinga, M. (2016). Principles of taxation. Eastern Africa: Jesuit Center for Theological Reflection, Jesuit Hakimani Centre and Jesuiten Weltweit. Retrieved December 27, 2017, from http://www.taxjusticeand-poverty.org/fileadmin/Dateien/Taxjustice_and_Poverty/Introduction/05_Principles.pdf

Listokin, Y. (2012). Equity, efficiency, and stability: The importance of macroeconomics for evaluating income tax policy. Yale Journal on Regulation, XXIX, 45-89.

Lyon, H. (1914). Principles of taxation. Boston: Houghton Mifflin Company, the University Press Cambridge.

MACPA's Legislative Resource Center. (2007, July 13). Top 10 criteria for evaluating proposed tax legislation. Retrieved from MACPA: https://www.macpa.org/top-10-criteria/

McCulloch, J. R. (1863). A treatish on the principles and practical influence of taxation and the funding system. Edinburgh: Adam and Charles Black.

McGee, R. W. (1997). Some principles of taxation for Latin America: Lessons from the USA and European experiences. Conference of the Business Association of Latin American Studies (pp. 1-17). Rio de Janeiro: Conference of the Business Association of Latin American Studies.

Meade, J. E. (1978). The structure and reform of direct taxation. London: George Allen \& Unwin.

Messere, K. C., \& Owens, J. P. (1985). International comparisons of tax levels: Pitfalls and insights. Retrieved from The Organization for Economic Cooperation and Development: https://www.oecd. org/eco/outlook/35589632.pdf

Nazarov, V. N. (2016). Tax system: The concept and its legal content. IEJME - Mathematics Education, $X I(7), 2195-2201$.

Nhekairo, W. A. (2014). The taxation system of Zambia. Lusaka: Jesuit Centre for Theological Reflection.

OECD. (1998). Electronic commerce: Taxation framework conditions. Ministers at the OECD Ministerial Conference - A Borderless World: Realising the Potential of Electronic Commerce (pp. 1-7). Ottawa: Committee on Fiscal Affairs of the OECD. Retrieved from https:/www.oecd.org/ctp/ consumption/1923256.pdf

OECD. (2014). Fundamental principles of taxation. In Addressing the Tax Challenges of the Digital Economy (pp. 29-50). OECD Publishing. doi:10.1787/9789264218789-5-en 
Ornäs Leijon, L. H. (2015). Tax policy, economic efficiency and the principle of neutrality from a legal and economic perspective. Uppsala: Uppsala University. Retrieved from http://uu.diva-portal.org

Preez, H. (2018). Constructing the fundamental principles of taxation through triangulation. The ATA Journal of Legal Tax Research, XVI(2). doi:10.2308/jltr-52190

Pyakurel, U., Kushiyait, B. K., \& Adhikari, I. (2013). Taxation and democracy in Nepal: Taxing land, labour and capital for achieving rights for everyone. South Asian Dialogues on Ecological Democracy, Nepal: Lalitpur.

Rangarajan, L. N. (1992). Kautilya: The arthashastra. (L. N. Rangarajan, Ed., \& L. N. Rangarajan, Trans.) New Delhi: Penguin Books India P. Ltd.

Ricardo, D. (1817). On the principles of political economy and taxation. Canada: Rod Hay's Archive for the History of Economics.

Ridge, M., \& Smith, S. (1991). Local taxation: The options and the arguments. London: Institute for Fiscal Studies (IFS). doi:http://dx.doi.org/10.1920/re.ifs.1991.0038

Rolfe, T. (2020, January 3). CIMA learning system 2007 financial accounting and tax principles. Retrieved from Google Books: https://books.google.com.np/books?id=rZKE9Vw2oqgC\&pg=PA3\&lpg=PA3\& $\mathrm{dq}=$ guiding + principles + of + good + tax + policy $+\mathrm{a}+$ framework + for + evaluating + tax + proposals $\&$ source $=$ bl\&ots $=$ XmTGqELjZV\&sig=ACfU3U0_cGdj3-asJrmf1hUjY4zin3O9DA\&hl=en\&sa=X\&ved=2ah UKEwil stePhvvnAhXmyDgGHeAD

Sawyer, A. (2019). Principles and frameworks for evaluating tax systems: A New Zealand perspective. Taxation Research Network Conference 2019 (pp. 1-28). New Zealand: University of Canterbury.

Shukla, N., \& Sharma, D. (2017). A review on construction of summated rating attitude scales. International Journal of Innovative Research in Multidisciplinary Field, III(7), 230-232.

Smith, A. (1776). An inquiry into the nature and causes of the wealth of nation. London: MacMillan \& Co.

Spector, P. E. (1992). Summated rating scale construction: An introduction. Newbury Park London: Sage Publications, Inc.

The Scottish Government. (2013). Principles for a modern and efficient tax system in an independent Scotland. Edinburgh: The Scottish Government. Retrieved from http://www.gov.scot/Resource/0043/00434977. pdf

Vedder, R. K., \& Gallaway, L. E. (1998). Some underlying principles of tax policy. Washington, DC: Joint Economic Committee. Retrieved from http://www.house.gov/jec/

Weier, A. (2006). Legal definitions of taxation terms - Implications for the design of environmental taxes and charges. Conference of the Australian Agricultural and Resource Economics Society (AARES) (pp. 1-16). Sydney: Conference of the Australian Agricultural and Resource Economics Society (AARES).

Weston, S. F. (1903). Principles of justice in taxation. New York: The Columbia University Press.

Wise, K., \& Berger, N. (2010). Understanding our tax system: A primer for active citizens. Massachusetts: Massachusetts Budget and Policy Center. 
